\title{
PELABELAN TOTAL TAK REGULER PADA GRAF BARBEL
}

\author{
Nugroho Arif Sudibyo ${ }^{1}$, Siti Komsatun ${ }^{2}$ \\ ${ }^{1,2}$ STMIK Duta Bangsa
}

\begin{abstract}
For example G (V, E) is a simple graph, a graph that do not contain of loops and parallel sides. Labeling of a graph is a mapping (function) that carries elements of a graph into positive or non-negative integers. Labeling power of irregular total point of a graph is a mapping $f: V \cup E \rightarrow\{1,2,3, \ldots, k\}$ which is called as labeling $\mathrm{k}$ total irregular point (vertex irregular total k-labeling) in $\mathrm{G}$, if the weight of each different point at $\mathrm{G}$ is not the same, that is $f(x)+\sum_{\boldsymbol{x y \epsilon E}} \boldsymbol{f}(\boldsymbol{x y}) \neq f(u)+\sum_{\boldsymbol{u} \boldsymbol{v} \boldsymbol{E}} \boldsymbol{f}(\boldsymbol{u} \boldsymbol{v})$ for each of the two points $x$ and $u$ that are different in G.Determination of exact value of irregular power of the total point is done by showing the value of lower limit and upper limit, both of them are proved to have equal value. The upper limit is decided by constructing a label, so that the largest label is obtained by minimum way. According to these two steps, a value for irregular power of the total point of a graph is obtained. In this paper, we will investigate irregular total labeling on barbell graph.
\end{abstract}

Keywords: Point Irregular Total Labeling, Barbell.

\section{PENDAHULUAN}

Pada tahun 1735, teori graf pertama kali diperkenalkan Leonhard Euler untuk menyelesaikan permasalahan jembatan Konigsberg pada sungai Pregel, Rusia. Solusi yang diusulkannya atas permasalahan tersebut berupa titik dan sisi yang kemudian dikenal sebagai graf Eulerian, yaitu suatu graf dengan karakteristik terhubung dan setiap titiknya berderajat genap. Selanjutnya teori graf berkembang luas dan dapat diterapkan pada kehidupan nyata. Pelabelan graf merupakan suatu topik yang menarik dalam teori graf sehingga berbagai jenis pelabelan diteliti dan dikembangkan (Gallian, 2017).

Hingga saat ini pelabelan graf dapat diaplikasikan pada berbagai bidang antara lain sistem transportasi, sistem komunikasi, navigasi geografis, radar, dan juga sistem keamanan. Sebagai contoh desain dari kode untuk sinyal radar dan peluru kendali ekuivalen dengan pelabelan pada graf lengkap, dimana setiap titik yang ada dihubungkan dengan satu sisi yang mempunyai label yang selalu berbeda. Label sisi ini menggambarkan jarak antar titik, sedangkan label titiknya merupakan posisi pada saat sinyal dikirimkan.

Pelabelan graf adalah suatu pemberian nilai (dengan bilangan bulat) pada titik atau sisi dari graf atau keduanya sehingga memenuhi kondisi tertentu. Label yang digunakan berupa bilangan bulat positif atau bilangan asli. Pelabelan graf pertama kali diperkenalkan pada akhir 1960an oleh Rosa. Selanjutnya, pelabelan yang domainnya berupa himpunan titik, himpunan sisi, atau keduanya biasanya disebut dengan pelabelan titik, pelabelan sisi, dan pelabelan total. Hingga kini dikenal beberapa jenis pelabelan graf yang dibahas, antara lain pelabelan graceful, pelabelan harmoni, pelabelan total tak 
beraturan, pelabelan ajaib, pelabelan radio, pelabelan anti ajaib, dan masih banyak pelabelan graf yang lain (Gallian, 2017).

Salah satu jenis pelabelan graf yang banyak dikaji dan dikembangkan adalah pelabelan total tak reguler. Ide pelabelan ini pertama kali Bača dkk.(2007). Misal $G(V, E)$ adalah graf sederhana.Pemetaan $f: V \cup E \rightarrow\{1,2,3, \ldots, k\}$ disebut pelabelan- $k$ total tak reguler titik(vertex irregular total $k$-labeling) pada $G$, jika bobot setiap titik yang berbeda pada G tidak sama, yaitu $f(x)+\sum_{x y \in E} f(x y) \neq f(u)+\sum_{u v \in E} f(u v)$ untuk setiap dua titik $x$ dan $u$ yang berbeda pada $G$. Penentuan kekuatan tak regular titik total suatu graf juga bukan hal yang mudah dilakukan dan sampai saat ini belum diperoleh hasil untuk graf secara umum.

\section{METODE PENELITIAN}

Penelitian ini merupakan kajian ilmu murni yang bersifat studi literatur. Oleh karena itu, pendekatan yang digunakan adalah eksploratif dan adaptasi yaitu memanfaatkan pengetahuan yang penulis miliki dari penelitian-penelitian sebelumnya. Selain itu digunakan juga hasil-hasil penelitian yang telah ada di literatur.

1. Menelusuri pustaka yang berupa buku-buku referensi, jurnal, artikel dan mengkaji konsep-konsep dasar yang berkaitan dengan graf, pelabelan pada graf dan khususnya pelabelan total tak reguler.

2. Mempelajari dan mengkaji beberapa hasil penelitian tentang pelabelan total tak reguler titik.

3. Melakukan penelitian tentang pelabelan total tak reguler titik pada ketiga kelas graf dan menentukan kekuatan tak reguler titik total (tvs $(G))$ pada graf-graf tersebut yang hasilnya disajikan dalam bentuk teorema.

4. Membuktikan teorema yang diperoleh di langkah 3. Untuk hal ini, detil langkahnya adalah sebagai berikut:

a. melakukan simulasi pelabelan total tak reguler titik pada graf tersebut di langkah ke 3 dengan jumlah titik $(n)$ tertentu.

b. menentukan rumus pelabelan total tak regular titik untuk $n$ sebarang pada graf tersebut,

c. menentukan batas atas dan batas bawah untuk $t v s(G)$.

\section{HASIL DAN PEMBAHASAN}

Graf barbel berorder $n \geq 3, B_{n, n}$ merupakan dua graf lengkap $K_{n}$ yang dihubungkan oleh bridge.Definisi ini diambil dari Gosh et al. (2006). Diberikan graf barbel $B_{n, n}, n \geq 3$ 
dengan $V\left(B_{n, n}\right)=\left\{v_{1}, v_{2}, \ldots, v_{n}, u_{1}, u_{2}, \ldots, u_{n}\right\}$ dan himpunan egde (garis) $E\left(B_{n, n}\right)=\left\{v_{l} u_{1}, u_{i} u_{j}\right.$, $\left.v_{i} v_{j} ; i, j=1,2, \ldots, n\right\}$.

Teorema 1.Diberikan graf barbell $B_{n, n}, n \geq 3$ maka kekuatan total tak reguler titik totalnya adalah

$$
\operatorname{tvs}\left(B_{n, n}\right)=3 \text {. }
$$

Bukti. Graf barbell $B_{n, n}$ merupakan graf yang memiliki $2 n$ titik. Dengan menggunakan Teorema pada Bača dkk.(2007) diperoleh batas bawah $\operatorname{tvs}\left(B_{n, n}\right) \geq 3$.Selanjutnya akan ditunjukkan bahwa $\operatorname{tvs}\left(B_{n, n}\right) \leq 3$. Misalkan himpunan titik $V\left(B_{n, n}\right)=\left\{v_{l}, v_{2}, \ldots, v_{n}, u_{1}, u_{2}\right.$, $\left.\ldots, u_{n}\right\}$ dan himpunan egde (garis) $E\left(B_{n, n}\right)=\left\{v_{l} u_{1}, u_{i} u_{j}, v_{i} v_{j} ; i, j=1,2, \ldots, n\right\}$. Pelabelan titik dan pelabelan garis untuk titik $v_{i}$ adalah sebagai berikut.

$$
\lambda\left(v_{i}\right)=1, \quad 2 \leq i \leq\left\lceil\frac{n}{2}\right\rceil
$$

dan

$$
\lambda\left(v_{i}\right)=2, \quad\left\lceil\frac{n}{2}\right\rceil<i \leq n
$$

dan untuk setiap $i, 1 \leq i \leq n$,

$$
\lambda\left(v_{i} v_{j}\right)=1, \quad 1 \leq j \leq n-i+1, i \neq j,
$$

dan

$$
\lambda\left(v_{i} v_{j}\right)=2, \quad n-i+2 \leq j \leq n .
$$

Berikut ini adalah pelabelan titik dan pelabelan garis untuk titik $u_{i}$.

$$
\lambda\left(u_{i}\right)=2, \quad 2 \leq i \leq\left\lceil\frac{n}{2}\right\rceil
$$

dan

$$
\lambda\left(u_{i}\right)=3, \quad\left\lceil\frac{n}{2}\right\rceil<i \leq n
$$

dan untuk setiap $i, 1 \leq i \leq n$,

$$
\lambda\left(u_{i} u_{j}\right)=2, \quad 1 \leq j \leq n-i+1, i \neq j,
$$

dan

$$
\lambda\left(u_{i} u_{j}\right)=3, \quad n-i+2 \leq j \leq n .
$$

Untuk garis yang menghubungkan diantara dua graf lengkap $K_{n}$ yang dihubungkan oleh bridgepelabelannya sebagai berikut.

$$
\lambda\left(v_{1}\right)=2, \quad \lambda\left(u_{1}\right)=3, \quad \lambda\left(v_{1} u_{1}\right)=3 .
$$

Oleh karena bobot setiap titik berbeda, maka terbukti kekuatan total tak reguler titik totalnya adalah $\operatorname{tvs}\left(B_{n, n}\right)=3$. 


\section{UCAPAN TERIMA KASIH}

Kemenristek Dikti yang telah mendanai penelitian ini pada tahun 2018.

\section{SIMPULAN DAN SARAN}

Kekuatan total tak reguler titik total dari graf barbel adalah 3.

\section{DAFTAR PUSTAKA}

Bača, M., Jendrol, S., Miller, M. dan Ryan, J. (2007). On irregular total labeling. Discrete Mathematics 307, 1378-1388.

Gallian, J.A. (2017).A Dynamic Survey of Graph Labeling.The electronic journal of combinatorics, 18, \#DS6.

Gosh, A., S. Boyd and A. Saberi.(2006), Minimizing Effective Resistance of a Graph, Proc $17^{\text {th }}$ International Symposium. Mathematics Theory, Network and Systems, Kyoto, Japan

Rosa, A. dan A. Kotzig. (1970). Magic Valuations of Finite Graphs, Canad. Math. Bull, 451-461 